\begin{tabular}{|c|c|c|}
\hline & $\begin{array}{l}\text { International Journal of Environment, Agriculture and Biotechnology } \\
\qquad \text { Vol-6, Issue-3; May-Jun, } 2021\end{array}$ & $\theta=$ \\
\hline IJEAB & $\begin{array}{c}\text { Journal Home Page Available: } \underline{\text { https://ijeab.com/ }} \\
\text { Journal DOI: } \underline{10.22161 / \text { ijeab }}\end{array}$ & \\
\hline
\end{tabular}

Article

Peer-Reviewed Journal

\title{
Effects of Season on Disease Frequency and Mortality of Poultry in Owerri Urban South-Eastern Nigeria
}

\author{
Akagha, N. U1*, Nwagbara, M. $\mathrm{O}^{2}$ \\ 1Department of Agricultural Technology, Imo State Polytechnic, Umuagwo-Ohaji, Nigeria. \\ ${ }^{2}$ Department of Soil Science and Meteorology, Michael Okpara University of Agriculture Umudike, Abia State Nigeria.
}

\section{Author's contributions}

This work was carried out in collaboration among all authors. Author ANU designed the study, performed the statistical analysis, wrote the protocol and wrote the first draft of the manuscript. Author NMO managed the analyses of the study, literature searches and helped with the discussions. Authors read and approved the final manuscript.

Received: 25 Jan 2021; Received in revised form: 16 Mar 2021; Accepted: 11 Apr 2021; Available online: 12 May 2021 (C2021 The Author(s). Published by Infogain Publication. This is an open access article under the CC BY license (https://creativecommons.org/licenses/by/4.0/).

\begin{abstract}
The study examined effects seasons have on diseases frequency and mortality of poultry birds in Owerri urban south-eastern Nigeria. The study therefore employed the use of secondary and primary data. Climatological data on rainfall, temperature, relative humidity and mortality of birds was collected from Nimet, Sam Mbakwe International cargo Airport, Imo State and ministry of livestock development Owerri respectively for a period of 16 years (2004-2019). Also 83 copies of questionnaire were used in the analysis. Results showed positive correlation between rainfall and relative humidity (0.517 and 0.747$)$ and an $R^{2}$ of $39.98 \%$ with implies that, the higher the rainfall the higher the relative humidity, and by extension the higher the frequency of deadly poultry diseases (Coccidiosis, Gumboro, Fowl cholera, Fowl typhoid) and mortality especially for broilers as the cell immune response of layer birds in defending itself against diseases and viruses are greater than that of broilers. While Newcastle diseases, Fowl pox, Fowl typhoid, chronic respiratory diseases mostly affect birds in the dry season (November-March). While Newcastle diseases, Fowl pox, Fowl typhoid, chronic respiratory diseases mostly affect birds in the dry season (November-March).In conclusion, seasons of the year affect poultry and its production in particular in Owerri urban. It is recommended that farmers should make sure they adopt proper roofing methods, as well as maintain good sanitation/hygiene practices to minimize heat and the occurrence and spread of diseases which may adversely affect birds across seasons.
\end{abstract}

Keywords - Season, poultry birds, diseases, mortality.

\section{INTRODUCTION}

Poultry are birds such as the domestic fowl, Turkey, Duck, Gesse, Ostrich etc which render not only economic services but contributes significantly to human food as a primary supplier of meat, egg and raw materials to industries (feathers, waste production). It also serves as source of income and employment to people compared to other domestic animals, their production is one that plays significant contribution to food for human consumption (Demeke, 2004). Poultry flocks are particularly vulnerable to climatic variations because there is a range of thermal conditions within which animals are able to maintain a relatively stable temperature (Adesiji, Baba and Tyabo, 2013).

In many African countries, poultry generally and its production in particular make substantial contribution to relive the protein insufficiency, about $80 \%$ of poultry production in Africa is found in rural and peril-urban areas where birds are raised in small numbers by the traditional extensive or semi - intensive, low input, low output systems (Faostat, 2012). Poultry production in Nigeria is an important component of the livestock sub-sector 
and has developed to the level of enterprise. Involving thousands of birds that provide employment, income, animal protein for rural and urban dwellers as well as manure for production of crop (Arhyel,et al., 2014). Poultry plays an important role for alleviating challenges associated with poverty in Nigeria (food security and malnutrition) and significantly contributes to women's income and help meet some level of household protein needs (Arhyel et al., 2014). It plays an important role in the diet and economy of Nigeria. Poultry birds are efficient converters of feed to egg and meat within a short period of time and in terms of nutritive value, poultry egg ranks second to cow milk (Adesiji et al., 2013). Agriculturists and nutritionists have generally agreed that developing the poultry industry of Nigeria is the fastest means of bridging the protein deficiency gap presently prevailing (Amos, 2006).

In Nigeria, there are two seasons, dry and rainy seasons. The rainy season begins by April and lasts till October whereas the dry season begins November and lasts till March (Odekunle, 2004). These seasons have their various effects not only on living things, poultry inclusive but also on non living things (Osaguona, et al., 2007). Season comes with various pathogenic disease occurrence, morbidity and mortality rate is majorly a factor of the type of management practices and vaccination of flocks (Kelly-Hope and Thomson , 2008). ). Poultry flocks are particularly vulnerable to seasonal changes because there is a range of thermal conditions within which animals are able to maintain a relatively stable body temperature in their behavioural and physiological activities (Ayo-Enwerem , Ahaotu, Nwogu and Opara, 2017).
Seasonal variation is one of the major threat to poultry production and also an important factor associated with incidences of diseases and mortality (Singh, et al., 2005; Nayak, et al., 2015). Disease and climate problems are seen as major limitations to modern animal husbandry in the tropical areas, coupled with high relative humidity in mostly chicken's pen, leads to mortality of young poultry birds (Smith, 2001). Variation due to season affects the severity and distribution of livestock diseases and parasites which adversely influence poultry production (Thornton, 2010). Diseases remains a major threat affecting the boost of the industry in Nigeria (Adewole, 2012). Major diseases are Newcastle diseases, Avian influenza, Avian pox, infectious burals diseases, coccidiosis, colisepticemia and worm infestation (Usman and Diarra, 2008). Due to diseases, productivity is reduced resulting to less meat, fewer eggs and high mortality. Therefore this study was carried out to investigate if seasons of the year have influence on disease frequency and mortality of chickens in the study area.

\section{MATERIALS AND METHODS}

\section{Study location}

Owerri, the Imo State capital lies at the intersection of six major roads of regional importance namely: Aba road, Okigwe road, Mbaise/Umuahia road and Orlu road. It is located within latitude $5^{\circ} 25^{\prime 10} \mathrm{~N}$ and $5^{\circ} 30^{\prime} 15 \mathrm{~N}$ and longitude $7^{\circ} 10 \mathrm{E}$ and $7^{\circ} 40^{\prime} \mathrm{E}$ and occupies a land area of about 104 square kilometers. It lies within the humid tropical climate with annual rainfall and temperature of over $2000 \mathrm{~mm}$ and $20^{\circ} \mathrm{C}$ respectively. And occupies a land area of about 104 square kilometers.

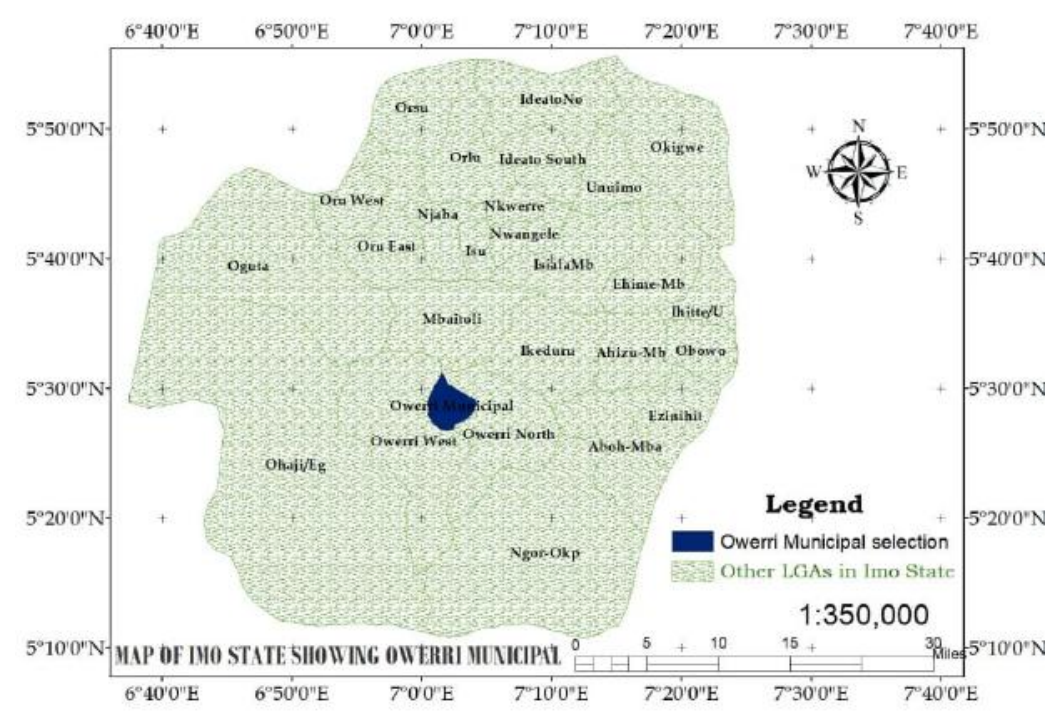

Fig.1: Map of Imo State showing Owerri Municipal 


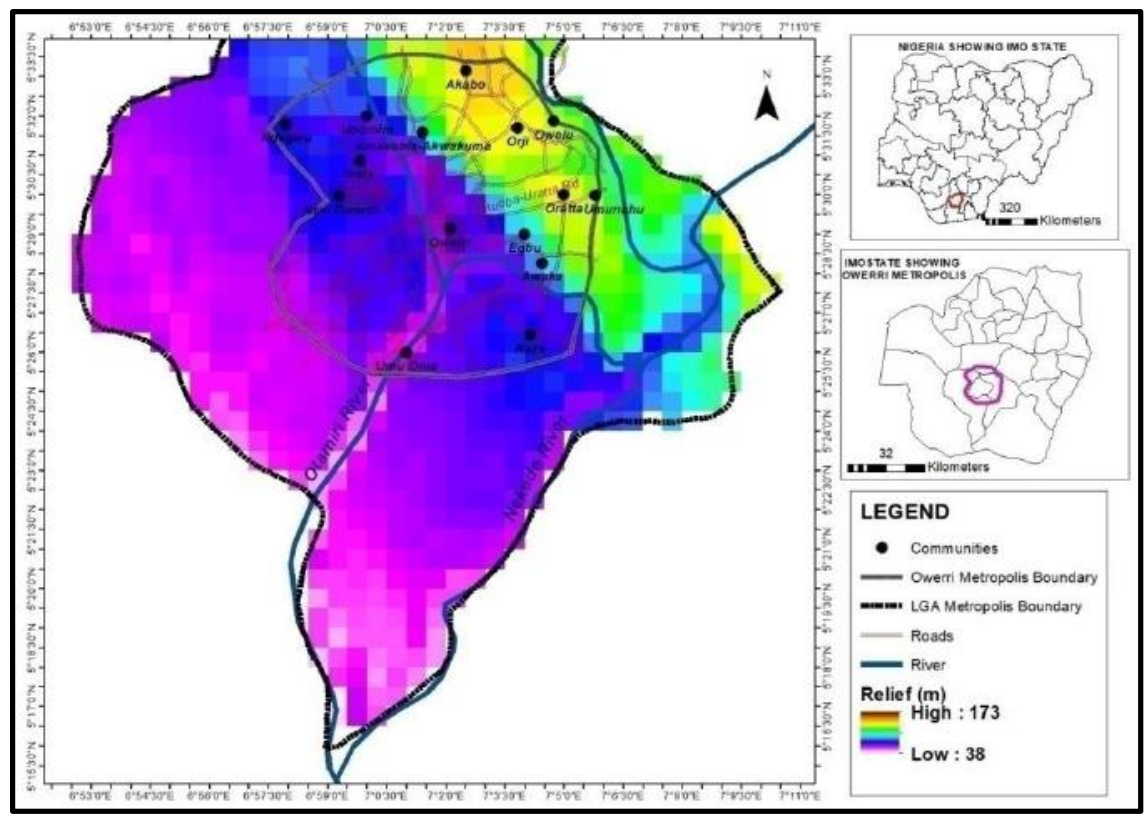

Fig.2: Relief and Drainage Map of Owerri Urban.

\section{Method of data collection}

The study deployed the quasi experimental research design. Data for rainfall, temperature, relative humidity and mortality was collected from Nigerian Meteorological Agency (NIMET) Sam Mbakwe International Cargo Airport Imo State and Ministry of Livestock Development Owerri for a period of 16 years respectively. Also 83 copies of questionnaire retrieved from farmers was used. Data was analyzed using Pearson's moment correlation, stepwise regression and linear regression to ascertain variations in disease/mortality across seasons from(20042019). The analysis was done using statistical package for social sciences (Spss version 21).

\section{RESULTS AND DISCUSION}

The table 1 shows monthly climatic data of maximum temperature, minimum temperature, mean temperature, relative humidity, total rainfall and number of birds mortality.

Table 1: Monthly climatic data and poultry mortality between 2004-2019

\begin{tabular}{|l|r|r|r|r|l|l|}
\hline \multicolumn{1}{|c|}{ Months } & \multicolumn{1}{l|}{$\begin{array}{l}\text { Max } \\
\text { Temp }\left({ }^{\mathbf{0}} \mathbf{C}\right)\end{array}$} & $\begin{array}{l}\text { Mini } \\
\text { Temp }\left({ }^{\mathbf{0}} \mathbf{C}\right)\end{array}$ & $\begin{array}{c}\text { Mean } \\
\text { Temp }\left({ }^{\circ} \mathbf{C}\right)\end{array}$ & $\begin{array}{c}\text { Relative } \\
\text { humidity }(\boldsymbol{\%})\end{array}$ & $\begin{array}{l}\text { Total rainfall } \\
(\mathbf{m m})\end{array}$ & $\begin{array}{c}\text { Number of } \\
\text { birds mortality }\end{array}$ \\
\hline JAN. & 31.7 & 18.1 & 24.9 & 78.6 & 22.1 & 75.1 \\
\hline FEB. & 34.4 & 22.9 & 28.7 & 71.8 & 40.2 & 66.0 \\
\hline MARCH & 34.7 & 21.9 & 28.3 & 76.3 & 85.6 & 67.9 \\
\hline APR. & 33.8 & 23.3 & 28.6 & 68.9 & 168.4 & 65.5 \\
\hline MAY & 32.4 & 23.1 & 27.7 & 80.6 & 272.5 & 71.6 \\
\hline JUN & 32.6 & 22.7 & 27.6 & 85.6 & 296.5 & 75.5 \\
\hline JUL & 30.1 & 22.6 & 26.4 & 87.3 & 342.7 & 77.6 \\
\hline AUG & 30.0 & 22.4 & 26.5 & 85.4 & 359.7 & 96.6 \\
\hline Sept & 31.5 & 22.6 & 26.8 & 85.2 & 339.1 & 69.8 \\
\hline OCT. & 31.7 & 22.6 & 27.2 & 79.1 & 219.6 & 72.0 \\
\hline NOV. & 32.9 & 21.3 & 27.1 & 69.9 & 55.6 & 55.9 \\
\hline DEC. & 33.5 & 21.0 & 27.2 & 69.4 & 42.6 & 64.3 \\
\hline
\end{tabular}

Source: Author's computation 2019 
The mean temperature, relative humidity and total rainfall shows significant variation in the seasons of the year, which has effect on diseases and mortality of poultry birds in Owerri Imo state, Nigeria. The months of rainy season (April-October), shows higher rainfall amount as follows $168.4 \mathrm{~mm}, \quad 272.5 \mathrm{~mm}, \quad 296.5 \mathrm{~mm}, \quad 342.7 \mathrm{~mm}, \quad 359.7 \mathrm{~mm}$, $339.1 \mathrm{~mm}$, and $219.6 \mathrm{~mm}$ and corresponds to increase in the mortality of poultry birds in the months of rainy season (April-October) at $65.5,71.6,75.5,77.6,96.6,69.8$ and 72.0. The month of August recorded the highest rainfall amount of $359.7 \mathrm{~mm}$ which corresponds with month of highest mortality rate of bird's at 96.6. Relative humidity revealed higher percentage in the months of rainy season (April-October), at 71.4\%, 80.6\%, 85.6\%, 87.3\%, 85.4\%, $85.2 \%$ and $79.1 \%$, while the months of the dry season (November-March) shows 69.9\%, 69.4\%, 56.6\%, 68.9\% and $76.3 \%$. Thus increase in relative humidity percentage concise with the months of rainy season (April-October), which shows that bird's mortality is higher in the rainy season.

\section{1: Effects of season on disease frequency and mortality of chickens}

The positive correlation value of (0.517 and 0.747), shows that the higher the relative humidity and rainfall for the years under investigation, the higher the probability of frequency of diseases and mortality of poultry birds. Relative humidity and rainfall which are indicators of rainy season are less than the alpha level of 0.05 and indicate that the two variables are statistically significant with disease frequency and mortality of poultry birds. Stepwise regression model was carried out to ascertain which predictor variables has more effect on diseases frequency and mortality of poultry birds. The regression model obtained has an $\mathrm{R}$ square value of 0.3998 which means about $39.98 \%$ variations in disease frequency and mortality of bird's is determined by relative humidity and rainfall.

Table 2: Regression model summary

\begin{tabular}{|l|r|r|r|r|r|}
\hline Model & \multicolumn{1}{|c|}{$\mathrm{R}$} & R Square & \multicolumn{1}{c|}{$\begin{array}{c}\text { Adjusted R } \\
\text { Square }\end{array}$} & $\begin{array}{l}\text { Std. Error of } \\
\text { the Estimate }\end{array}$ & \multicolumn{1}{c|}{$\begin{array}{l}\text { Durbin- } \\
\text { Watson }\end{array}$} \\
\hline 1 & $.302^{\mathrm{a}}$ & 0.3998 & .175 & 577.37060 & .973 \\
\hline
\end{tabular}

Table 3: Anova for regression model

\begin{tabular}{|rl|r|r|r|r|r|}
\hline \multicolumn{1}{|l|}{ Model } & & Sum of Squares & Df & Mean Square & \multicolumn{1}{|c|}{ F } & Sig. \\
\hline \multirow{2}{*}{1} & Regression & 1776987.162 & 2 & 592329.054 & 1.7768620 & $.0043^{\mathrm{b}}$ \\
& Residual & 2666854.505 & 9 & 333356.8131 & & \\
& Total & 4443841.667 & 11 & & & \\
\hline
\end{tabular}

The regression model obtained in table 2 is statistically significant since the Sig. value of 0.0043 in table 3 is not greater than alpha level of 0.05 . We therefore conclude that relative humidity and rainfall amount have effect on disease frequency and mortality of poultry birds in the study area within the years under investigations.

The stepwise regression model obtained from the statistically significant regression coefficient is as follows:

diseases frequency and birds mortality $=10361.83+0.171$ *relative humidity $+22.79 *$ rainfall + crror

\section{2: Trends of seasonal variations in disease frequency and mortality}

The trend analysis shows seasonal variation in disease frequency and mortality of birds, for the months of January and July for the span under investigation. The months of January represents the dry season while the months of July represents the rainy season for a period of sixteen years (2004 - 2019). The mortality plot also was used to access outbreak of poultry disease.

Figure. 3 and figure. 4 indicates trend analysis for diseases and mortality of birds in January and July for all the years under investigation. 


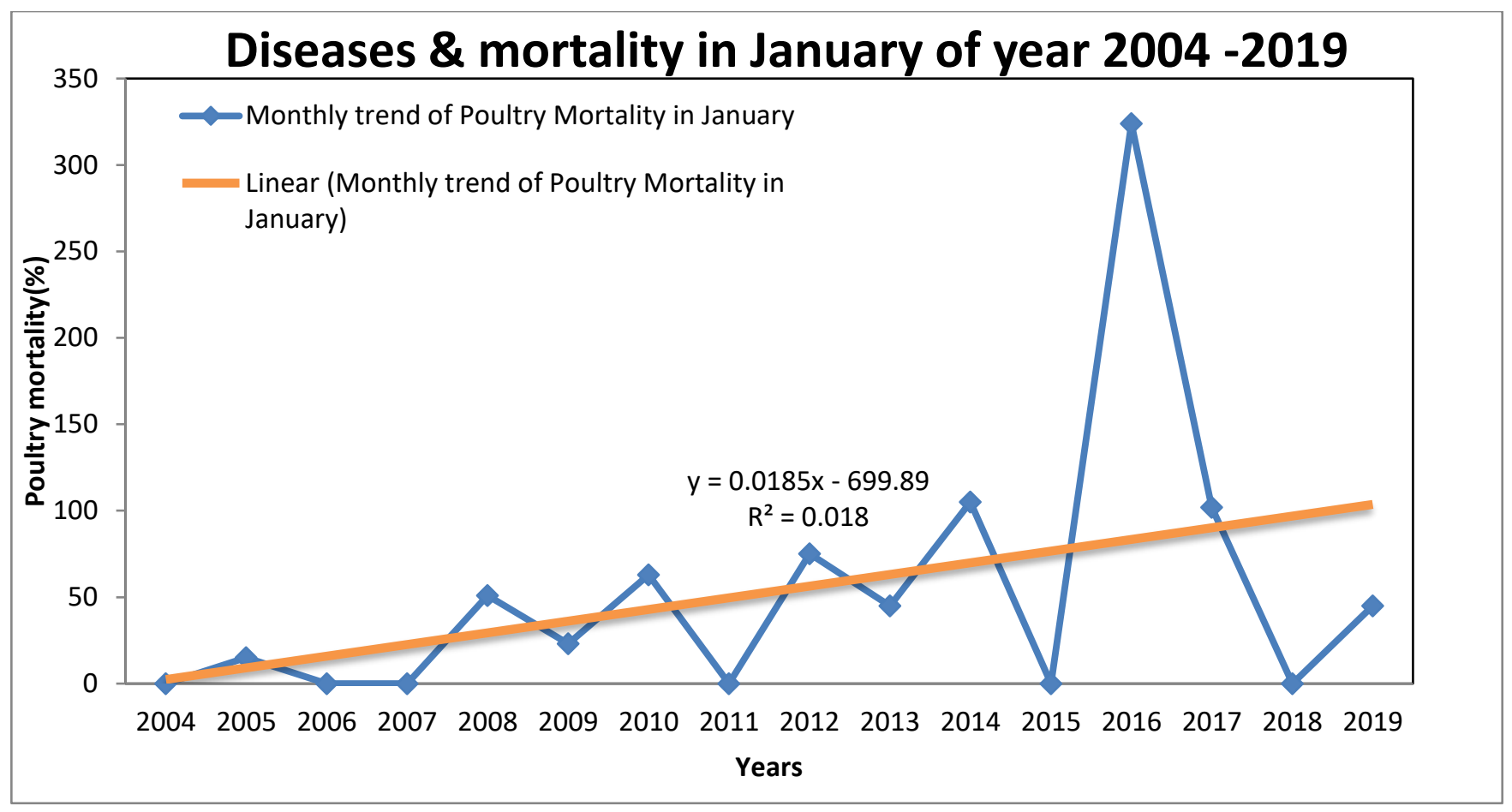

Fig.3: Trend analysis of diseases and mortality in the month of January for all the years

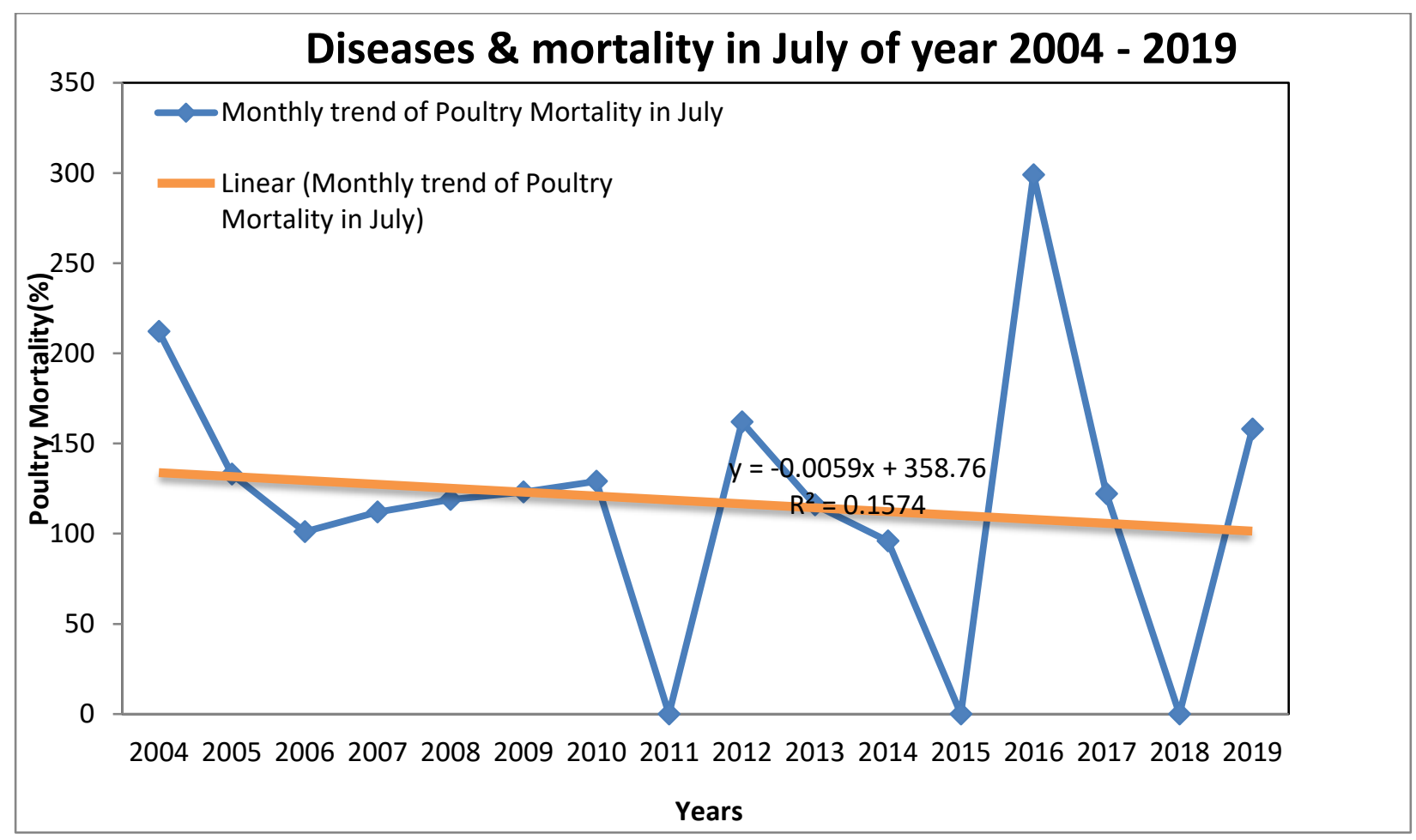

Fig.4: Trend analysis of diseases and mortality in the month of July for all the years

The trend analysis in figure 3 (January) and figure 4 (July), shows fig 3 possess a downward trend which is a decrease in disease frequency and mortality of birds in January. While fig 4 shows an upwards trend which is an increasing trend in disease frequency and mortality of birds in July.
The months of January revealed a trend equation of $\mathrm{y}=0.0185 \mathrm{x}-699.89$ with an $\mathrm{R}^{2}$ of 0.018 . While the months of July revealed a trend equation of $\mathrm{y}=0.0059 \mathrm{x}+358.76$ with an $\mathrm{R}^{2}$ of 0.1574 . The trends shows seasonal variation 
in disease frequency and mortality rate affecting poultry birds across the seasons.
Table 4 shows statistics report of the answers provided by the respondents who attended to the structured questionnaire for this research purpose.

Table 4: Percentage effects of seasons on frequency of diseases and mortality

\begin{tabular}{|c|c|c|c|c|c|c|}
\hline $\begin{array}{l}\text { Question } \\
\text { Code }\end{array}$ & $\begin{array}{l}\text { Effects of seasons on } \\
\text { frequency of poultry } \\
\text { diseases and mortality }\end{array}$ & $\begin{array}{l}\text { (UD) \% } \\
\text { UNDECIDED }\end{array}$ & $\begin{array}{l}\text { (SD)\% } \% \\
\text { STRONGLY } \\
\text { DISAGREED }\end{array}$ & $\begin{array}{l}\text { (D) } \% \\
\text { DISAGREED }\end{array}$ & $\begin{array}{l}\text { (A)\% } \\
\text { AGREED }\end{array}$ & $\begin{array}{l}\text { (SA)\% } \\
\text { STRONGLY } \\
\text { AGREED }\end{array}$ \\
\hline D1 & $\begin{array}{l}\text { In dry season (Nov- } \\
\text { March)birds are mostly } \\
\text { affected by Newcastle } \\
\text { diseases, fowl pox, fowl } \\
\text { typhoid, chronic } \\
\text { respiratory diseases. }\end{array}$ & 0.069 & 0.000 & 0.000 & 1.000 & 1.793 \\
\hline D2 & $\begin{array}{l}\text { In rainy season (April-Oct) } \\
\text { birds are mostly affected } \\
\text { by coccidiosis, Gumboro, } \\
\text { fowl cholera, fowl typhoid. }\end{array}$ & 0.310 & 0.000 & 0.000 & 0.690 & 1.862 \\
\hline D3 & $\begin{array}{l}\text { During the harmattan (Dec- } \\
\text { Feb) mortality rate is high. }\end{array}$ & 0.138 & 0.000 & 0.310 & 1.034 & 1.379 \\
\hline D4 & $\begin{array}{l}\text { Increase in mortality rate } \\
\text { after harmattan (Feb - } \\
\text { March) due to high } \\
\text { environmental temperature. }\end{array}$ & 0.276 & 0.000 & 0.517 & 0.552 & 1.517 \\
\hline D5 & $\begin{array}{l}\text { Newcastel disease, fowl } \\
\text { pox, fowl typhoid, fowl } \\
\text { cholera is frequent in rainy } \\
\text { season. }\end{array}$ & 0.345 & 0.793 & 1.724 & 0.000 & 0.000 \\
\hline D6 & $\begin{array}{l}\text { Coccidiosis, Gumboro, } \\
\text { fowl cholera, fowl typhoid } \\
\text { is frequent in dry season. }\end{array}$ & 0.414 & 1.552 & 0.897 & 0.000 & 0.000 \\
\hline D7 & $\begin{array}{l}\text { Mortality of poultry birds } \\
\text { is higher in dry season } \\
\text { (Nov-Oct). }\end{array}$ & 0.310 & 2.000 & 0.552 & 0.000 & 0.000 \\
\hline D8 & $\begin{array}{l}\text { Mortality of poultry birds } \\
\text { is higher in rainy season } \\
\text { (April - Oct). }\end{array}$ & 0.172 & 0.000 & 0.000 & 0.483 & 2.207 \\
\hline D9 & $\begin{array}{l}\text { Fowl pox, fowl typhoid, } \\
\text { fowl cholera, chronic } \\
\text { respiratory diseases, can } \\
\text { occur in any season, but } \\
\text { frequent in the dry season } \\
\text { (Nov - March) }\end{array}$ & 0.448 & 0.862 & 1.552 & 0.000 & 0.000 \\
\hline D10 & $\begin{array}{l}\text { Fowl pox, fowl typhoid, } \\
\text { fowl cholera, chronic } \\
\text { respiratory disease can } \\
\text { occur in any season but } \\
\text { frequent in the rainy season } \\
\text { (April - Oct.) }\end{array}$ & 0.379 & 0.000 & 0.000 & 0.966 & 1.517 \\
\hline
\end{tabular}


The table 4 shows the percentage of different ways the farmers in the study area responded on the effects of seasons on frequency of poultry diseases and mortality. Out of 83 respondents, $2.207 \%$ which is the highest strongly agreed that mortality of poultry birds is higher in the rainy season (April-Oct), while $0.483 \%$ agreed and $0.172 \%$ are undecided on the effect. $1.862 \%$ of respondents strongly agreed that Coccidiosis, Gumboro, Fowl cholera, Fowl typhoid are mostly frequent in the rainy season (April-Oct), $0.690 \%$ agreed and $0.310 \%$ are undecided of any season. $1.793 \%$ strongly agreed that
Newcastle diseases, Fowl pox, Fowl typhoid, chronic respiratory diseases mostly affect birds in the dry season (Nov- March), $1.000 \%$ of respondents agreed and $0.069 \%$ are undecided of any season. $1.517 \%$ of respondents agreed that Fowl pox, Fowl typhoid, Fowl cholera, chronic respiratory disease can occur in any season but frequent in the rainy season (April - Oct.), $0.966 \%$ agreed, while $0.379 \%$ are undecided of any season. The block diagram shows responses on effects of seasons on the frequency of disease and mortality.

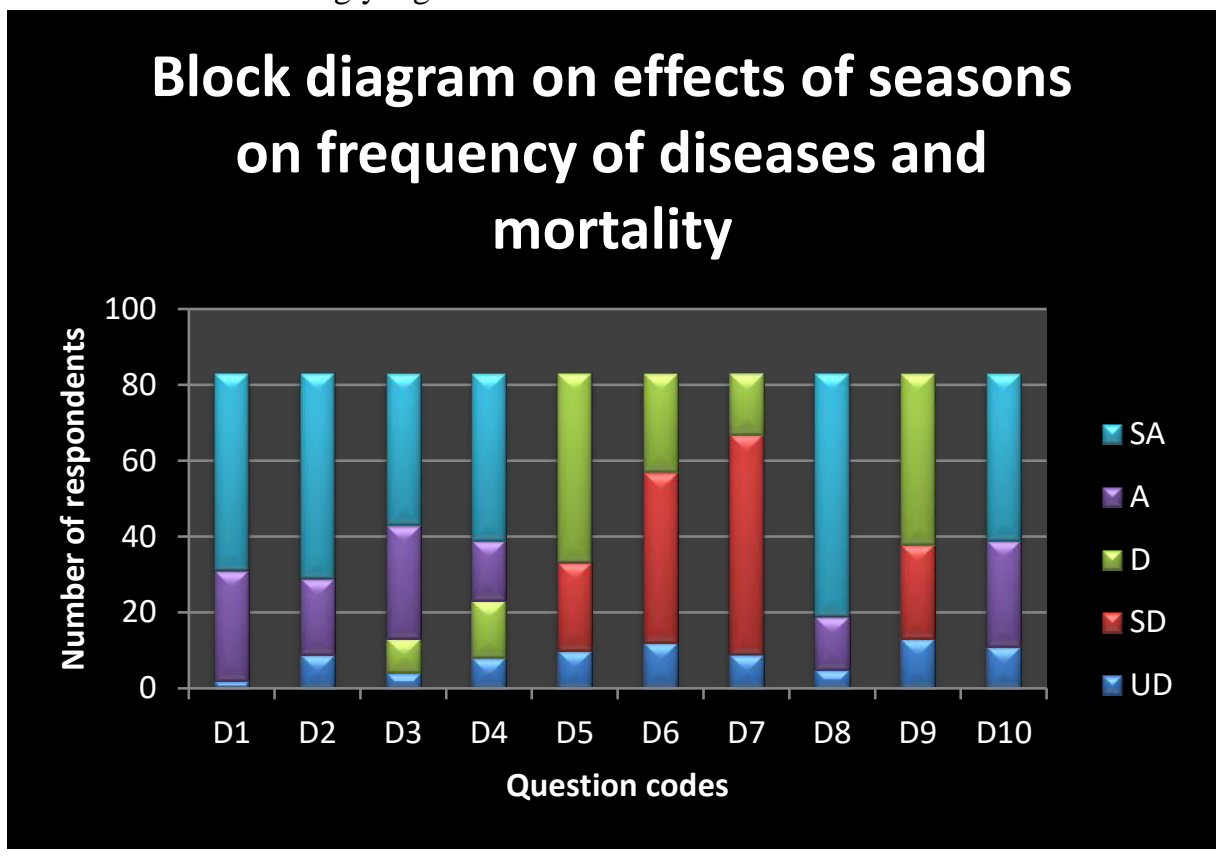

Fig.5: Responses on effects of seasons on frequency of disease and mortality.

\section{CONCLUSION}

The correlation analysis on effects of seasons of the year on disease frequency and mortality of chickens was carried out and it revealed a positive $(r=0.517$ and $r=0.747)$ with relative humidity and rainfall which are indicators of season. It implies that the higher the relative humidity and rainfall for the years under consideration, the higher the frequency of diseases and mortality of poultry birds, therefore seasons of the year have influence on disease frequency and mortality of chickens in the study area. The co-efficient of determination (CD) obtained, which is in percentage implies that $39.98 \%$ of disease frequency and mortality is explainable by relative humidity and rainfall which are indicators of the rainy season. This report is in agreement with (Uddia et al., 2010) who noted that rainy season are most vulnerable to various poultry diseases.(Sato et al., 2002), also noted that, due to cold stress birds increase their susceptibility to a number of infectious and non -infectious agents. Also (Nayak et al.,
2015), noted that higher rainfall and relative humidity increases diseases incidence on poultry birds.

\section{RECOMMENDATION}

It is recommended that farmers should make sure they select species that are suitable and can resist the prevailing conditions due to variability in season in the study area as well as to the prevailing diseases. There is also the need for appropriate stocking of birds for free movement and space, adoption of proper roofing methods, vaccinating the birds when due, maintaining good sanitation/hygiene practices to minimize heat and the occurrence and spread of diseases which may adversely affect birds across seasons.

\section{COMPETING INTERESTS}

Authors have declared that no competing interest exits. 


\section{REFERENCES}

[1] Adesiji, G.B., Tyabo, I.S., Bolarin, O., Ibrahim, M. and Baba, S.T. (2013) Effects of climate change on poultry production in Ondo State, Nigeria. Ethiop. J. Environ. Stud. Manage., 6(3): 242-248.

[2] Adewole, O. (2012). The efficacy of drugs in the treatment of coccidiosis in chicken in selected poultries. Acad. Res. Int., 2: 210-220.

[3] Amos, T. T. (2006). Analysis of Backyard Poultry Production in Ondo State Nigeria. International Journal of Poultry Science volume 5(5): 247- 250

[4] Arhyel, G. B., Ndahi, J. I. Zaifada, A. U., Mustapha, M. Jarafu, D. J., Asogwa, N. T. and Hajara, S. (2014). A retrospective study of poultry diseases diagnosed in Maiduguri, North-East, Nigeria. POUHFISH wildiSci ISSN: 2375-46.

[5] Ayo-Enwerem, M.C; Ahaotu, E.O; Nwogu, C. M. and Opara, J. (2017a). Growth performance of starter broilers fed diets containing red sandalwood (Pterocarpussantolinoides) leaf meal. Direct Research Journal of Veterinary Medicine and Animal Science. 2 (4): 106-109.

[6] Demeke, Solomon, (2004). Egg production and performance of local and white Leghon hens under intensive and rural household conditions in Ethopia. LRD 16:2.

[7] Faostat(2012). http://faostat.fao.org/site/340/default/as px, viewed on 19- 22/03/2007.

[8] Kelly-Hope and Thomson (2008). Climate and Infectious Diseases.springer Nertherlands 31-71.

[9] Nayak, G. D. Behura, N. C., Sardar, K. K. and Mishra, P.K (2015) Effect of climatic variables on production and reproduction traits of colored broiler breeder poultry. Veterinary world, ESSN: $2231-0416$.

[10] Odekunle, T.O.(2004). Rainfall and the length of growing season in Nigeria. International journal of Climatology 24(4), 467-479.

[11] Osaguona, P.O, Fajobi, E. A, Meduna, A.J ,Irokanulo,U.O, Ayeni, S.M and Ogunjobi, J.A.(2007). Effect of climate variation on the environment. Proceedings of the Association of women in Forestry and Environment 167170.

[12] Sato, T, Tezuka Shibuya, H., Watanabe, T. Kamata, H. and Shirai, W. (2002). Cold induced ascities in broiler chickens and its improvement by temperature controlled rearing. Avian Diseases, 46, 989-996.

[13] Smith, T. (2001). Caring for plants in the Retail Setting. University Massachusetts extension service Leaflet (accessed November, 2014).

[14] Singh , R, Shanker, H, Arora, B.M ,Singh, V.P.(2005). Studies on morbidty and mortality pattern in cattle of the organized farms of different agro- climatic conditions in ultra Pradesh. Indian Journal of Animal Health . 44: 47-53.

[15] Thornton , P.K(2010). Livestock production : recent trend ,future prospects. PhilosTrans .R. SocBiolosci 365: 28532867.
[16] Uddia, M. B. Ahemd, S. S. U., Hassan, M. M., Khan, S. A. and Mamum, M. A. (2010) Prevalence of poultry diseases at Narsingdi Bangladesh. Int. J. Bio. Res. 1(6): 09-13.

[17] Usman, B. A. and Diarra, S. S. (2008). Prevalent diseases and mortality in egg type layers. An overview. int. j. poulty. sci. 7:304-310. 